\title{
"WOULD MONEY MAKE A DIFFERENCE?": HOW EFFECTIVE CAN THE RULE-OF-LAW-BASED PROTECTION OF FINANCIAL INTERESTS IN THE EU STRUCTURAL AND ENLARGEMENT POLICY BE?
}

\author{
Aleksandar-Andrija Pejović, PhD \\ Independent EU consultant \\ Kumborski put 41, 85346, Kumbor, Herceg-Novi, Montenegro \\ aleksandar.andrija@gmail.com
}

\begin{abstract}
In recent years, the rule of law and, especially, its "proper" implementation has become one of the most debated topics in Europe in recent years. The "Big Bang Enlargement" marked the beginning of dilemmas whether the new EU Member States fulfil the necessary rule of law criteria and opened the way for divergent views on how to implement TEU Article 2 values in practice. Furthermore, constant problems and difficulty of the candidate countries to fulfil the necessary rule of law criteria added to the complexity of the problem. In turn, the European institutions have tried to introduce a series of mechanisms and procedures to improve the oversight and make the states follow the rules - starting from the famous Treaty on the European Union (TEU) Article 7, the Rule of Law Mechanism, annual reports on the rule of law and the most recent Conditionality Regulation.
\end{abstract}

The Conditionality Regulation was finally adopted in December 2020 after much discussion and opposition from certain EU Member States. It calls for the suspension of payments, commitments and disbursement of instalments, and a reduction of funding in the cases of general deficiencies with the rule of law. On the other hand, similar provisions were laid out in the February 2020 enlargement negotiation methodology specifying that in the cases of no progress, imbalance of the overall negotiations or regression, the scope and intensity of pre-accession assistance can be adjusted downward thus descaling financial assistance to candidate countries.

The similarities between the two mechanisms, one for the Member States, the other for candidate countries shows an increased sharing of experiences and approaches to dealing with possible deficiencies or breaches of the rule of law through economic sanctioning, in order to resolve challenges to the unity of the European union. The Covid-19 pandemic and the crisis it has provoked on many fronts has turned the attention of the Member States (i.e. the Council) away from the long running problematic issues. Consequently, the procedures against Poland and Hungary based on the Rule of Law Mechanism have slowed down or become fully stalled, 
while certain measures taken up by some European states have created concerns about the limitations of human rights and liberties.

This paper, therefore, analyses the efforts the EU is making in protecting the rule of law in its Member States and the candidate countries. It also analyses the new focus of the EU in the financial area where it has started to develop novel mechanisms that would affect one of the most influential EU tools - the funding of member and candidate countries through its structural and enlargement policy. Finally, it attempts to determine and provide conclusions on the efficiency of new instruments with better regulated criteria and timing of activities will be and how much they would affect the EU and its current and future member states.

Keywords: rule of law, financial interests, Western Balkans, EU, Covid-19

\section{INTRODUCTION}

The breach of the fundamental values of the TEU Article $2,{ }^{1}$ and more concretely the rule of law, pertains to the most serious violation of the Union acquis. This matter touches upon the most sensitive and core values which should be unequivocally ensured and shared among the Member States. In order to have a Union across which the acquis is equally valid in all its constituent members, there needs to be a common understanding about what these values are, along with a full and indubitable respect and commitment to them. Numerous examples of various views on what the rule of law is abound in theoretical research. ${ }^{2}$ At the same time, the practical side of it, i. e. how the rule of law should be practically implemented, monitored, safeguarded and sanctioned in the cases of possible violations, has shown that the rule of law is becoming an ever more divisive issue for the EU.

Article 2 of the Treaty on European Union: "The Union is founded on the values of respect for human dignity, freedom, democracy, equality, the rule of law and respect for human rights, including the rights of persons belonging to minorities. These values are common to the Member States in a society in which pluralism, non-discrimination, tolerance, justice, solidarity and equality between women and men prevail" - Treaty of Lisbon amending the Treaty on European Union and the Treaty establishing the European Community [2007] OJ C306/01

2 More on this from extensive literature that exists: Tamanaha, B., On the Rule of Law, History, Politics, Theory, Cambridge University Press, Cambridge 2004; Peerenboom, R. Varieties of Rule of Law: An Introduction and Provisional Conclusion, Asian Discourses of Rule of Law, Routledge Curzon, 2014; Skaaning, S.; Moller, J., Systematizing Thin and Thick Conceptions of the Rule of Law, APSA 2010 Annual Meeting Paper, 2010; Beaulac S., What Rule of Law Model for Domestic Courts Using International Law in States in Transition: Thin, Thick or 'A La Carte', Transitional Justice Institute Research Paper No. 10-13, 2019; Peirone F., The Rule of Law in the EU: Between Union and Unity, 15 Croatian Yearbook of European Law \& Policy, No. 57, Zagreb, 2019.; Palombella, G., The Rule of Law as an Institutional Ideal, The Rule of Law and Democracy, in: L. Morlino L.; Palombella, G. (eds.), Internal and External Issues, Brill Publishing, 2010.; Raz, J., The Rule of Law and Its Virtue, in: Raz, J. (ed.), The Authority of Law: Essays on Law and Morality, Clarendon Press, Oxford, 1979. 
What is more problematic is the fact that the EU has been entirely unprepared for rule of law backsliding in its democratic Member States. ${ }^{3}$

Proposals for and the already implemented monitoring and reporting mechanisms that came in the last decade have bourgeoned, but rarely succeeded to alter or stop the deteriorating state of the rule of law in the EU. In recent years, the EU has tried to bring together the initiatives and contingency procedures such as TEU Article 7, the Rule of Law Framework, and annual reports on the rule of law; it has finally established the European Public Prosecutor's Office and in the recent period invested considerable efforts to bring the issue of the rule of law to the forefront of the budgetary discussions with the proposed new mechanisms of financial conditionality based on the respect for the rule of law. This has added to the ongoing debate on how to find a way of dealing with the growing problem of opposing views on what the rule of law is, how it is to be respected, promoted and protected - in tandem to preserving the Union as it is.

This article tries to answer the question whether the new mechanism of the recently adopted Conditionality Regulation together with the existing rule of law mechanisms will start to make change with its better regulated procedures, stricter deadlines and more focus on the funds that are disbursed to the Member States. It also tries to address the introduction of a similar conditionality for the enlargement countries, where the rule of law should condition disbursement of pre-accession assistance. These two recent initiatives have been welcomed by those who advocate the rule of law as a sine qua non for the survival of the Union based on the common values where no aberrations are allowed. Time shall say if this move will help unity or actually lead to more misunderstandings and difficulties for the 'European project'.

\section{RULE OF LAW AND EU INSTITUTIONS}

The already famous TEU Article 7 is a prime and the most valued example of the sanctioning mechanism that can be used to protect the value of the rule of law in the EU. It has been towering over the two Central European Member States, but also over the unity and future of the European Union as we know it. The European Council conducted a hearing of the two states for the clear risk of a serious breach of the rule of law by the authorities of Poland and Hungary. However, it has not yet formally started a discussion on Article 7 directed at Poland through

Kochenov, D., The Acquis and Its Principles, The Enforcement of the 'Law' versus the Enforcement of 'Values' in the EU, in eds. Jakab, A.; D., The Enforcement of EU Law and Values, Ensuring Member States' Compliance, Oxford University Press, Oxford, 2017, p. 24. 
the procedure initiated by the European Commission four years ago, nor directed at Hungary following the initiative of the European Parliament (EP) in 2018. The only similar action of this sort was the one with Austria after the election of the extreme right-wing Haider Government in 2000. In the words of Cramer and Wrange "The Haider affair, in a sense, put the finger on a gap between the basic idea prevailing in the treaty on European Union... and the common values of human rights". ${ }^{4}$ The failure to enact a cordon sanitaire against the ruling coalition and the subsequent withdrawal of measures after the Three Wise Men Report, ${ }^{5}$ ended the experiment with the suspension of certain rights of the Member State concerned. Consequently, the whole affair had such a profound effect on the Council that Member States have been reluctant to openly act in a similar way towards their fellow Member State in the Council. In spite of this, Article 7 was further strengthened to clarify procedures in the cases of similar problems with fellow Member States. However, the procedures still allow the Council to decide on a common position without time-constraints, and allow for the process of sanctioning to continue. Considering the challenges that the EU has been facing, it would be, difficult, therefore, to predict when or whether the European Council will hold a debate on Poland and Hungary, which would be the next required step according to the procedures, or to vote with four-fifths of Member States on the finding of risk to the rule of law in the Member State(s) concerned.

The von der Leyen Commission slowly but steadily continued along the steps of its predecessors. In its Communication on 'Further Strengthening the Rule of Law in the Union' ${ }^{6}$ it cautiously stated that the Council's progress in two cases (Poland and Hungary) of activating Article 7 could have been more significant and that the Council should have established new procedures for implementing it in practice. At the same time, it stated the need to set up an early warning mechanism for detecting breaches of the rule of law. In July 2019, the EC published its outline for action in the field of the rule of law. ${ }^{7}$ Through the Plan, the Commission announced it would work to deepen the process of monitoring developments in the

4 Cramer, P.; Wrange, P, The Haider Affair, Law and European Integration, SSRN Electronic Journal, 2001, p. 55

5 Report on the Austrian Government's Commitments to the Common European Values, in Particular Concerning the Rights of Minorities, Refugees and Immigrants, and the Evolution of the Political Nature of the FPO (The Wise men Report) by Martti Ahtisaari, Jochen Frowein, Marcelino Oreja, Paris, 8 September 2000.

6 Communication from the Commission to the European Parliament, the European Council and the Council, Further strengthening the Rule of Law within the Union State of play and possible next steps, COM/2019/163 final Brussels, 3 April 2019.

7 Communication from the Commission to the European Parliament, the European Council, the Council, the European Economic and Social Committee and the Committee of the Regions Strengthening the rule of law within the Union, A blueprint for action COM/2019/343 final, 17 July 2019. 
field of rule of law in the Member States through the so-called 'rule of law review cycle'. This initiative became one of the most critical issues for the Council in the ensuing debate as Poland and Hungary opposed the proposal, but ultimately they could not prevent the review. The resulting review became a reality in September 2020 with the Rule of Law Report. ${ }^{8}$ The scope of the report includes the existence of systemic problems in the law-making process, the ability of member states to fight corruption, media pluralism and freedom, and the ability of the judiciary to function independently. The basis of the Report is found in the Venice Commission's rule of law checklist. ${ }^{9}$

This Member State-by-Member State assessment of 27 country complements other EU instruments such as the EU Justice Scoreboard, the European Semester, and the most recent Next Generation EU instrument. However, the annual assessment will take time to become truly effective and have a deterrent effect. A significant challenge is the time required for the new mechanism to really take root and have an impact. During that time, however, certain Member States could further develop their vision and version of the rule of law and insist on national and constitutional identity, as can be seen in the case of Hungary and Poland, but also in the case of the already reasoned judgment of the Federal Constitutional Court of Germany in the Weiss case. ${ }^{10}$

The Commission will continue to review the effectiveness of the existing procedure for identifying breaches of the acquis, as well as call on the Council to clearly support its efforts to establish unambiguous deadlines and guidelines when the Rule of Law Framework is activated. There is also a question of further non-functionality of the system if, for example, after the Commission initiates proceedings before the Court of Justice of the EU and this results in a certain member state still not complying with a judgment of the Court. In that case, the Commission is left with only a fine in accordance with Article 260 TFEU, with the Commission determining the amount of the lump sum or penalty to be paid by the Member State which it considers appropriate in the circumstances. In this context, the question could immediately be asked how high the punishment would have to be in cases of violation of the rule of law to really provoke a reaction from a member state. In the proceedings so far, fines have proven to be effective, however the question is if they could apply to fundamental values and produce the wanted effect. It

8 Communication from the Commission to the European Parliament, the Council, the European Economic and Social Committee and the Committee of the Regions - 2020 Rule of Law Report, The rule of law situation in the European Union, COM/2020/580 final, 30 September 2020, Brussels.

9 European Commission for Democracy through Law (Venice Commission) Rule of Law Checklist, CDL-AD (2016)007rev, Strasbourg, 18 March 2016.

10 BVerfG, Judgment of the Second Senate of 5 May 2020 - 2 BvR 859/15 -, paras. 1-237. 
remains to be seen whether the Commission and Council's approach, which Pech, Wachowiec and Mazur call "oscillation between procrastination and dereliction of duties ... endangering the functioning of the EU legal order" ${ }^{11}$ will transform into a more coherent and unison mechanism of dealing with the risks to the EU law and the unity of the Union.

On the other hand, the European Parliament, having less restrictions than the Council or the Commission, and considering its political nature, has already proposed concrete procedural changes in the area of the rule of law. The directness of the changes is best summed up its 'Resolution on the Rule of Law Mechanism' from 2016. ${ }^{12}$ Namely, the EP proposed that Article 2 TEU and the Charter of Fundamental Rights become the legal basis for legislative measures adopted in the ordinary legislative procedure, as well as to enable national courts to initiate proceedings before the Court of Justice of the European Union in regard to the legality of procedures of the Member States. It was also suggested that Article 7 TEU be reviewed in order to determine appropriate and applicable sanctions against any Member State, in order to to identify which rights of Member States that are at fault (including voting rights in the Council) could be suspended. It could also include, for example financial sanctions or the suspension of Union funding, which was a harbinger of the Conditionality Regulation ${ }^{13}$ provisions. The EP also proposed that one third of Members of Parliament be allowed to report to the Court of Justice on Union legislation, once adopted and before its enforcement. It is also proposed that natural and legal persons directly or individually affected by the action bring actions before the Court of Justice of the EU for alleged violations of the Charter, either by Union institutions or by a Member State, by amending Articles 258 and 259 TFEU. The issues that the EP pinpointed, raise a very important question on whether the existing procedures in the Treaty and the mechanisms already established leave too much flexibility and manoeuvre-space for the Member States concerned.

The Court of Justice of the European Union ensures that the law is observed in the interpretation and application of the Treaties (TEU Article 19), thus its primary concern is that each Member State has the same understanding of the principle of the rule of law. The application of this principle has to be common and the rules

11 Pech, L.; Wachowiec, P.; Mazur D., Poland's Rule of Law Breakdown: A Five-Year Assessment of EU's (In) Action, Hague Journal on the Rule of Law, The Hague, 2021, p. 42.

12 European Parliament Resolution with recommendations to the Commission on the establishment of an EU mechanism on democracy, the rule of law and fundamental rights (2015/2254(INL)), Brussels, 25 October 2016.

13 Regulation (EU, Euratom) 2020/2092 of the European Parliament and of the Council of 16 December 2020 on a general regime of conditionality for the protection of the Union budget. 
have to be the same, a fact that has been confirmed on multiple occasions through the case law ${ }^{14}$ making the Court into one of the most important custodians of the rule of law in the EU. This practice will only increase since there a number of ongoing rule of law cases before the Court. ${ }^{15}$ What is more, the case law of the Court is having an impact on the preparation of the candidate countries ${ }^{16}$ for their reforms and adaptation to the EU standards through the negotiation of the Judiciary and Fundamental Rights Chapter. It is, therefore, expected that the Court of Justice through its judgments will additionally clarify the constituent issues pertaining to the rule of law, such as the independence of the judiciary, judicial protection, etc, ${ }^{17}$ thus aiding other institutions and advocates of the common approach to this divisive issue.

As it can be seen, the European Institutions have approached the issue of the rule of law from various angles in the past period. The Council, the Commission, the EP and the Court have all added to the build-up of mechanisms and tools the intention of which is to position the rule of law as a necessary respected criterion in all Member States alike. In this process, the EU needs to ensure that through this approach to the rule of law, it does not undermine, or even destroy, adherence to the principle of the rule of law in the Member States. ${ }^{18}$ The fine balance between the forces pulling indifferent directions is best seen in the Council, which is the most cautious institution in the decision-making process on the rule of law. Recent developments regarding the acquis that should regulate the conditionality between the respect of the rule of law and the financial means at the disposal of the Member States demonstrate the same causality of relationships and problematics that have marked the processes with other rule of law tools.

14 For example, the most articulate ones include: Judgment of 23 April 1986, Les Verts v. Parliament, 294/83, EU:C:1986:166; Judgment of 27 February 2018, Associação Sindical dos Juízes Portugueses, C64/16, EU:C:2018:117; and Judgment of 25 July 2018, Minister for Justice and Equality (Deficiencies in the system of justice), C216/18 PPU, EU:C:2018:586.

15 For example, the most recent Advocate General's Opinions in Cases C-487/19 W.Ż. (Chamber of Extraordinary Control and Public Affairs of the Supreme Court - Appointment) and C-508/19 Prokurator Generalny (Disciplinary Chamber of the Supreme Court - Appointment), where the Advocate General found that the two newly-created chambers of the Polish Supreme Court are liable to fail the requirements established by EU law in a situation where the judges concerned were appointed to those positions in flagrant breach of the national laws applicable to judicial appointments to that Court.

16 Matić Bošković, M., Role of Court of Justice of the European Union in Establishment of EU Standards on Independce of Judiciary, EU and Comparative Law Issues and Challenges Series (ECLIC), Vol. 4, Osijek, 2020, p. 332.

17 Lenaerts, K., New Horizons for the Rule of Law Within the EU, German Law Journal, CUP, 2020, p. 34.

18 Kochenov, D.; Bard, P., Rule of Law Crisis in the New Member States of the European Union: The Pitfalls of Overemphasising Enforcement, Reconnect, 2018, p. 26. 


\section{THE RULE OF LAW CONDITIONALITY}

Conditionality is a tool that uses conditions attached to the provision of benefits an instrument that the European Union has been traditionally using in its external mechanisms, either in its trade policies with third countries, or in its neighbourhood and enlargement policy. The nature of this conditionality has been mostly unilateral, the EU being the sole party in the process that "conditions and then decides". ${ }^{19}$ The Copenhagen Criteria ${ }^{20}$ represent the most explicit example of prescribed conditions that regulate the enlargement process on a "take-it-or-leave-it" basis. In certain cases, a pre-accession conditionality regime was transferred over after the accession date, as in the example when unfulfilled rule of law obligations of Bulgaria and Romania continued to be a condition through a post-accession Cooperation and Verification Mechanism. ${ }^{21}$ In recent years, conditionality has increasingly gained more importance within the European Union, as one can see with the entry requirements to the 'eurozone' or to Schengen. Finally, it has also gradually transformed into an "EU internal governance mechanism" that is utilised to "foster compliance, change domestic regulatory frameworks, implement EU policies, encourage structural reforms and advance a wide array of EU objectives at the national level through the route of EU budget". ${ }^{22}$ This means that budget conditionality may be credibly used for the purpose of strengthening the authority of the rule of law.

Consideration of EU financial interests through multiannual financial framework and EU budget has always been one of the key worries of the EU. The Commission has aspired to defend the Union's budget against generalised deficiencies, thus aiming to develop efficient and overarching mechanisms that guarantee the safeguard of the huge amounts of financial means it is disbursing to the Member

19 Vlajković, M., Uslovljavanje u spoljnoj politici Evropske unije: Izazovi pravno-političkog „izvoza“ vrednosti u susedstvo, Međunarodno javno i krivično pravo u XXI veku, Udruženje za međunarodno krivično pravo, Tara, 2020, p. 318.

20 Membership requires that candidate country has achieved stability of institutions guaranteeing democracy, the rule of law, human rights, respect for and protection of minorities, the existence of a functioning market economy as well as the capacity to cope with competitive pressure and market forces within the Union. Membership presupposes the candidate's ability to take on the obligations of membership including adherence to the aims of political, economic and monetary union - European Council Conclusions, Copenhagen, 21-22 June 1993, p. 1

21 The Mechanism for Cooperation and Verification has been designed by the European Commission to monitor the post-accession implementation of commitments of Bulgaria and Romania in the area of judicial reform, corruption and organised crime. Although set up as a transitional measure in 2007, it is still valid for these two Member States.

22 Vita, V, Revisiting the Dominant Discourse on Conditionality in the EU: The Case of EU Spending Conditionality, Cambridge Yearbook of European Legal Studies, Centre for European Legal Studies, Cambridge, 2017, p. 28. 
States and its institutions. This is essential if it wants to take care of its revenues, expenditures and assets covered by, acquired through, or due to the Union budget and the budgets of the institutions, bodies, offices and agencies established under the Treaties and budgets managed and monitored by them. The added element to the already existing mechanisms of protecting financial interests is the rule of law element as a necessary pre-condition for any disbursement of financial means. The funds allocated through the EU budget should thus be conditioned not by adhering to financial rules that protect the financial interests of the Member States, but by more indirect links to the respect of the rule of law. The underlining idea is that a Member State has to respect the rule of law principle and apply it according to the agreed rules, otherwise it lacks the credibility of the system and the state that is to spend the Union's budgetary means.

To put it at in concrete terms, Poland and Hungary should jointly receive more than EUR 150 billion $^{23}$ in the 2014-2020 financial perspective (114.7 and 35.5 billion euros respectively). Depriving them of this money because of evidenced general deficiencies with the rule of law could cause far-reaching consequences for those governments that rely on these allocations in their budget programming and disbursement. Put into the words of Commission Vice-President Verra Jourová, the mechanism's capacity for encouraging countries like Hungary and Poland to act according to the bloc's principles through financial pressure can be summed up as: "The one who can't understand the values, can understand the money". ${ }^{24}$ The conditionality of the budget disbursement on the basis of the respect of the rule of law is thus one of the most sensitive and divisive issues that burdens the discourse of the Council in the recent period. The impact of this rule of law-based-financialconditionality remains to be seen, but even the long preparations that led to its application have caused much disharmony and trouble.

\section{THE DIALOGUE LEADING TOWARDS THE ADOPTION OF THE CONDITIONALITY REGULATION}

In the context of the growing initiatives and calls for a more strengthened conditionality on the European funds, on 15 May 2018, the Commission established the 'Proposal for a Regulation of the Council establishing the Multiannual Finan-

23 Summary of 2014-2020 EU budget amounts assigned to EU countries for support for specific programmes in the Cohesion Policy and the Common Agricultural Policy, European Commission, [https://ec.europa. eu/info/strategy/eu-budget/long-term-eu-budget/2014-2020/spending/pre-allocations_en], Accessed 15 April 2021.

24 Maukonen, R., Verra Jourová: EU underestimated the role of media in upholding democracy, International Press Institute, 17 Febryary 2021, [https://ipi.media/vera-jourova-eu-underestimated-the-role-of-media-in-upholding-democracy/], Accessed 15 April 2021. 
cial Framework (MFF) for the period 2021-2027', ${ }^{25}$ which would have the possibility for the Council to adjust the MFF ceilings or to allow "re-budgeting" as a consequence of the lifting of suspension measures decided under the protection of the Union's budget in the case of generalised deficiencies as regards the rule of law in the Member States. The primary aim of the Commission was, therefore, to enhance the link between core values and the distribution of budget funds, i. e.to condition the distribution of EU money on compliance with the rule of law so that EU money no longer funded those governments that do not abide by the rule of law. This was to be done through a new regulation that would specify a general regime of conditionality for the protection of the Union budget.

The European Council concluded on 21 July 2020 that the Union's financial interests should be protected in accordance with the general principles embedded in the Union Treaties, in particular the values of Article 2 TEU, and underlined the importance of the protection of the Union's financial interests and the respect of the rule of law. ${ }^{26}$ This conclusion came after an unusually long European Council meeting and deliberations that took five days (the usual time frame being two days), at the end of which the EU leaders reached a landmark €1.82 trillion budget with a recovery package that includes $€ 390$ billion worth of grants and $€ 360$ billion worth of loans for dealing with the consequences of the Covid-19 pandemic. The deal on a "conditional regime to protect the budget" was adopted after a long debate and a sharp rift between the Member States. In the end, everybody was, at least to the public, left 'satisfied'. While European Council President Charles Michel stated that it was the first time in European history that the rule of law is a decisive criterion for budget spending, the Prime Minister of Poland, Mateusz Morawiecki expressed his satisfaction that there was no link between the rule of law and funds in the proposed deal. ${ }^{27}$

The general language of the conclusions and these contrasting public statements actually meant that additional discussions were necessary in order to have a compromise to be reached at the latest by the December 2020 European Council i. e. before the start of the next financial perspective 2021-2028. The German Presidency took the tough task of preparing Council Conclusions that would make all the sides satisfied. The compromise on the Multiannual Financial Framework, Next Generation EU and consequently the biggest stumbling block in the nego-

25 Proposal for a Council Regulation laying down the multiannual financial framework for the years 2021 to 2027, COM/2018/322 final - 2018/0132 (APP).

26 European Council Conclusions, Brussels, 17-21 July 2020.

27 Gehrke, L, How Europe reacted to the new EU budget and coronavirus recovery fund deal, Politico, 21 July 2020 [https://www.politico.eu/article/madness-and-historic-day-europe-reacts-to-the-budget-deal/], Accessed 15 April 2021. 
tiations - the so-called Conditionality Regulation, was finally reached in December 2020. However, the European Council in its conclusions also provided an interpretation of the start of the application of the Conditionality Regulation i. e. the effective implementation of the newest rule of law mechanism.

The interpretative language of the Conclusions was actually a catalyst for the compromise adoption of the full package. The Commission was invited to "develop and adopt guidelines on the way it will apply the Regulation" ${ }^{28}$ in close consultation with the Member States. However, before the Commission could do that, the European Council actually envisaged the suspension of the application of the Regulation in the case of an action for annulment is introduced. This would mean that the Commission cannot propose measures under the Regulation and the guidelines cannot be finalised before the judgment of the Court of Justice "so as to incorporate any relevant elements stemming from such judgment".

Obviously, this formula created a lot of stir and various opinions about the "legality of the interpretative declaration" and the award of "a great victory to Orbán and Kaczyński" and "watering down the mechanism". ${ }^{29}$ When preparing the Conclusions and defining the language of the possibility to legally challenge the regulation, it was apparent that Hungary and Poland would go that way and thus try to protract as long as possible the application of the act. Although there is an element of finality - as the Court of Justice of the EU will come up with its judgement, either through an emergency procedure (less likely) or in an ordinary one (more likely), and in the case the Court acknowledges the legality of the Conditionality Regulation the start of its application would not be without problems. Essentially, hitting "offending nations in the wallet" 30 could appear to hit back as an extremely strict conditionality sanction that could very much affect the unity of the Council and the overall EU. Already the investment of energy, time and struggle that both sides concerned had put into this extremely politically sensitive process shows us all the magnitude of the problem the EU is facing with the question of the rule of law respect and the mechanisms to protect it.

28 European Council Conclusions, Brussels, 10-11 December 2020.

29 Scheppele, K. L.; Pech, L.; Platon, S., Compromising the Rule of Law while Compromising on the Rule of Law, VerfBlog, 2020/12/13, [https://verfassungsblog.de/compromising-the-rule-of-law-while-compromising-on-the-rule-of-law/], Accessed 15 April 2021, p. 1.

30 Heinemann, F, Going for the Wallet? Rule-of-Law Conditionality in the Next EU Multiannual Financial Framework, Inter- economics, Vol. 53, No. 6, Nov.-Dec. 2018, p. 297. 
The response of the EP, shortly after the European Summit, was, as per usual, very direct and came in the form of a Resolution; ${ }^{31}$ it welcomed the historical political agreements on a EUR 1.8 trillion package and a functioning Rule of Law conditionality. However, it expressed its strong regret that "due to the unanimity rule in the Council", the adoption of the entire package was unduly delayed and reminded that the "content of the European Council conclusions on the Regulation on a general regime of conditionality for the protection of the Union budget is superfluous". It also stressed that the conclusions of the European Council "cannot be made binding" on the Commission in applying legal acts. They underlined that the Parliament would defend the validity of the Regulation before the Court and it would expect the Commission to do the same. Finally, it also announced its readiness to activate Article 265 TFEU to lodge an action for failure to act against the Commission in the case of no activity from the EC. However, although a legal opinion was prepared by the EU Parliament's legal service addressing the legality of the EUCO Conclusions, the decision of the EP Committees was "not to bring a legal action against the Conclusion" on 22-23 February 2021. ${ }^{32}$ Thus, although the EP was quite direct in its December 2020 Resolution, it refrained from entering a legal struggle with the Council over the legality of its Conclusions.

Eventually, as was expected, Hungary and Poland launched a legal challenge against the Conditionality Regulation at the Court of Justice of the EU on 11 March 2021. On this occasion, the Hungarian Justice Minister Judit Varga stated that they could not accept that EU legislation "which seriously infringes legal certainty" ${ }^{3}$ be kept in force. On the other hand, the Polish Government was even more direct stating that the EU "has no competence to define the concept of 'the rule of law' or to lay down the conditions for assessing compliance with underlying principles". ${ }^{34}$ Warsaw based its initiative on the belief that the solutions as expressed in the Conditionality Regulation "do not have a legal basis in the Treaties, interfere with the competences of the Member States and infringe the law of

31 Motion for a Resolution to wind up the debate on the statements by the Council and the Commission pursuant to Rule 132(2) of the Rules of Procedure on the Multiannual Financial Framework 20212027, the Inter-Institutional Agreement, the EU Recovery Instrument and the Rule of Law Regulation (2020/2923(RSP), B9-0428/2020, 14 December 2020.

32 Alemanno, A., The EU Parliament's Abdication on the Rule of Law (Regulation), VerfBlog, 2021/2/25, [https://verfassungsblog.de/the-eu-parliaments-abdication-on-the-rule-of-law-regulation/], Accessed 15 April 2021.

33 Poland and Hungary file complaint over EU budget mechanism, Deutsche Welle, 11 March 2021, [https:// www.dw.com/en/poland-and-hungary-file-complaint-over-eu-budget-mechanism/a-56835979], Accessed 15 April 2021.

34 Zalan, E., Poland and Hungary challenge rule-of-law tool at EU court, euobserver, 12 March 2021, [https://euobserver.com/political/151211], Accessed 15 April 2021. 
the European Union" ${ }^{35}$ as well as that the disbursement of funds from the Union budget should be made subject only to the fulfilment of objective and specific conditions that clearly arise from legal provisions.

At the same time, Members of the European Parliament, in their debate on the same day, requested an expedited procedure at the Court to produce a judgment as soon as possible. ${ }^{36}$ Furthermore, the EP adopted a new Resolution on the Conditionality Regulation on 25 March 2021 where they repeated their strong political language of the previous December 2020 Resolution on the same subject; and urged the Commission to adopt the guidelines under the regulation and provide Parliament with information on it by 1 June 2021. In the case it fails to perform this, the "Parliament will consider this to constitute a failure to act and subsequently shall take against the Commission under Article 265 TFEU". ${ }^{37}$ At the time of finalising this article, the Court had not rendered a Decision on the respective cases.

\section{THE CONDITIONALITY REGULATION MECHANISMS}

Aside from all the criticism on the implementation approach that the Council set forth for the Conditionality regulation, this act bestowed a very clear and defined mechanism of dealing with various deficiencies of the rule of law. Article 3 of the Conditionality Regulation specifies indicative breaches of the rule of law as those endangering the independence of the judiciary. Also, a breach could be a failure to prevent, correct or sanction arbitrary or unlawful decisions by public authorities, including by law-enforcement authorities, withholding financial and human resources affecting their proper functioning or failing to ensure the absence of conflicts of interest. Finally, limiting the availability and effectiveness of legal remedies, including through restrictive procedural rules and the lack of implementation of judgments, or limiting the effective investigation, prosecution or sanctioning of breaches of law could also be considered as violation of the rule of law.

At the same time Article 4 defines the breaches of the principles of the rule of law in relation to this Regulation in the field of the proper functioning of the

35 Skarga do Trybunału Sprawiedliwości UE, Kancelaria Prezesa Rady Ministrow, 11 March 2021, [https://www.gov.pl/web/premier/skarga-do-trybunalu-sprawiedliwosci-ue], Accessed 15 April 2021.

36 Application of Regulation (EU, Euratom) 2020/2092, the rule of law conditionality mechanism (debate), European Parliament, 11 March 2021, [https://www.europarl.europa.eu/doceo/document/CRE-92021-03-11-ITM-005_EN.html], Accessed 15 April 2021.

37 Resolution on the application of Regulation (EU, Euratom) 2020/2092, the rule-of-law conditionality mechanism, 2021/2582(RSP), Brussels, 25 March 2021. 
authorities implementing the Union budget and the authorities carrying out financial control, monitoring and audit. Furthermore, the proper functioning of investigation and public prosecution services in relation to the investigation and prosecution of fraud, including tax fraud, corruption or other breaches of Union law relating to the implementation of the Union budget or to the protection of the financial interests of the Union will also be under scrutiny. An effective judicial review by independent courts of actions or omissions by the authorities referred to in the previous points will also fall under the scope of the Regulation. The prevention and sanctioning of fraud, including tax fraud, corruption or other breaches of Union law relating to the implementation of the Union budget or to the protection of the financial interests of the Union are all important elements of this act. Furthermore, the imposition of effective and dissuasive penalties on recipients by national courts or by administrative authorities, as well as the recovery of funds unduly paid are under the focus of the Regulation. Finally, effective and timely cooperation with OLAF and with the EPPO in their investigations or prosecutions and other situations or conduct of authorities that are relevant to the sound financial management of the Union budget or the protection of the financial interests of the Union are an integral part of the Regulation's scope.

Based on such established breaches, the Commission may, in cases of direct or indirect management, suspend payments or of the implementation of the legal commitment, prohibit entering into new legal commitments; suspend the disbursement of instalments in full or in part or an early repayment of loans guaranteed by the Union budget; suspend or reduce the economic advantage under an instrument guaranteed by the Union budget; and prohibit entering into new agreements on loans or other instruments guaranteed by the Union budget. Where the Commission implements the Union budget under shared management with Member States, it can suspend the approval of one or more programmes or an amendment thereof; suspend or reduce commitments; including through financial corrections or transfers to other spending programmes; reduce pre-financing; interrupt payment deadlines; and finally suspend payments. Throughout all this period, the Commission is obliged to keep the European Parliament and the Council informed of any measures proposed, adopted or lifted.

The procedures of imposing and lifting of measures under the Regulation are best presented in a visual form as they require a very complex mechanism of decision making followed by an involvement of a number of stakeholders. 
Table 1: Imposing of measures according to the Conditionality Regulation

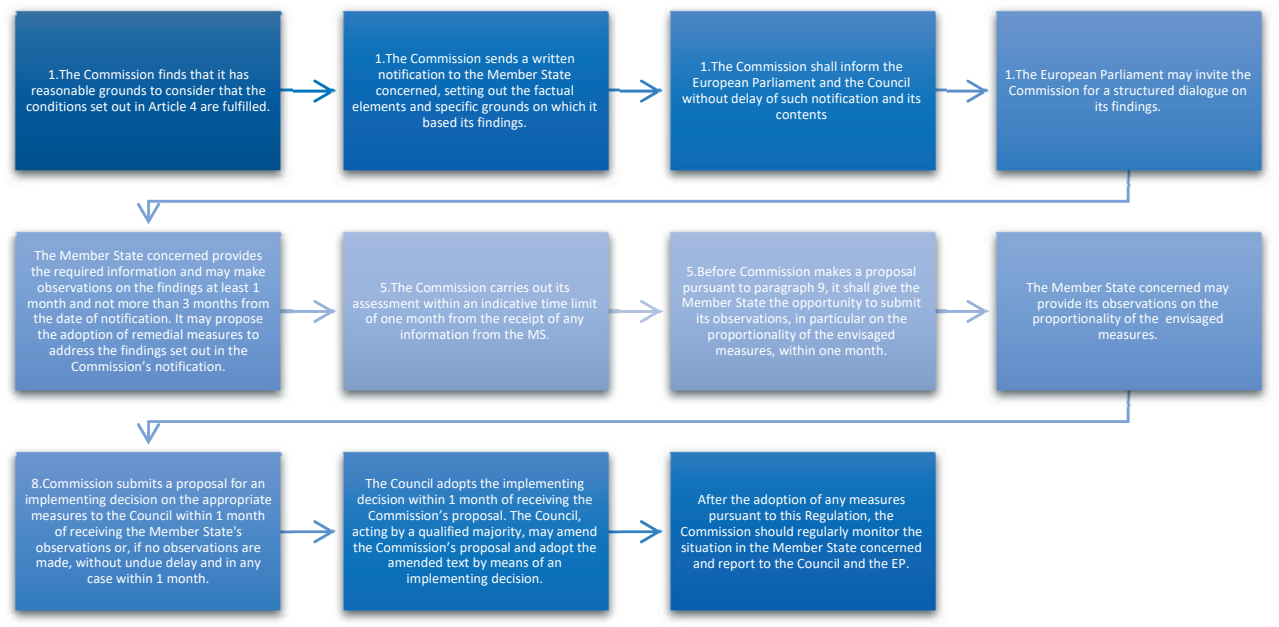

Table 2: Lifting of measures according to the Conditionality Regulation
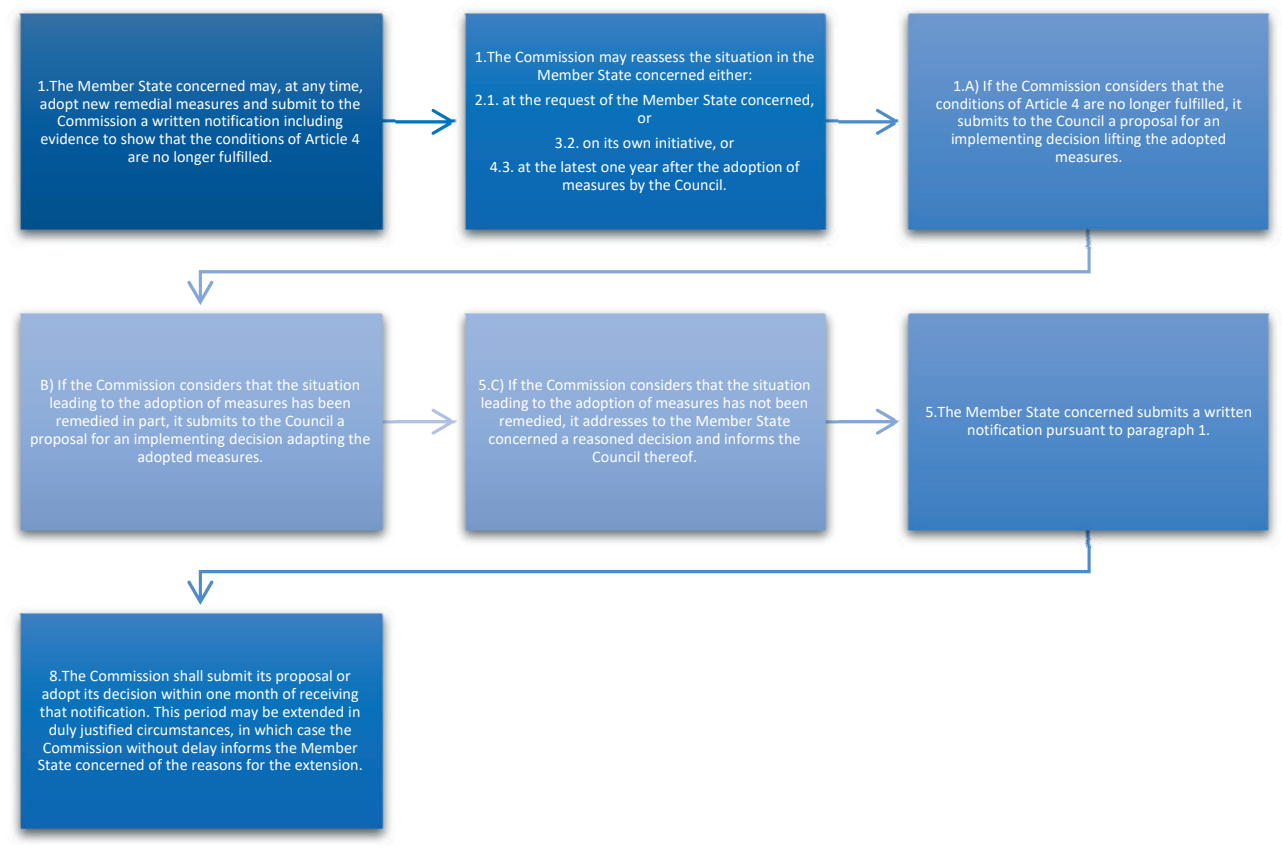

It remains to be seen how the Commission will devise the guidelines for the full implementation of the Regulation in the light of the Council's December 2020 instructions. Justice Commissioner Reynders gave assurances that these instructions to the Commission did not bring any substantial change in terms of substance because the text of the Regulation remained the same after the discussion in 
the European Parliament, and that his services are working on the guidelines and collecting evidence from the Member States. ${ }^{38}$

Nonetheless, one can note the very cautious approach and a lot of safety measures before the measures are imposed on a Member State, as well as the omnipresent role of the Council and the EP in the procedures. Elaborate, too complicated, but also, at some points, under-regulated procedures have provided for procrastination of the decision-making within the Article 7 mechanism. The communication and correspondence that the Commission has with a Member State concerned may come in the form of written notifications, structured dialogues, provision of information, observations and proposals. This opens up possibilities for protracting the process while the controversial practices in the Member States related to the rule of law breaches continue unimpeded and at the same time the distribution of EU funding flows unstintingly - even more so in the case of the Next Gen rapid disbursement of the financial means.

Unlike, however, the Article 7 procedures, the Conditionality Regulation now prescribes deadlines and thus limits the possibility of delaying decisions once the notification is delivered to the Member State concerned until the implementing decision is adopted by the Council. This sets an element of finality to the whole process meaning that, once the procedures have been launched, there are strict deadlines to be followed. No matter what the future guidelines by the Commission would be, and on the condition that the Conditionality regulation does not get successfully legally challenged, it would be very important to see the implementation of the provisions of the regulation are applied and the deadlines respected on a practical level. This would be key not only for the sake of the very Conditionality Regulation status, but could also provide an invigorating example for the two Article 7 procedures and very much influence any such mechanism to be used in the enlargement arena.

\section{THE ENLARGEMENT PROCESS AT THE ACTUAL MOMENT}

The Conditionality Regulation, in its preamble (para 4 and 5), notes that the accession criteria established by the Copenhagen European Council in 1993 and strengthened by the Madrid European Council in 1995 are the essential conditions that a candidate country has to satisfy to become a Member State of the Union (Article $49 \mathrm{TEU})$. It also underlines that once a candidate country becomes

38 Democracy Institute Event Offers Debate on the Rule of Law in Europe, Central European University, 26 January 2021, [https://www.ceu.edu/article/2021-01-26/democracy-institute-event-offers-debate-rule-law-europe], Accessed 15 April 2021. 
a Member State, it joins a legal structure that is based on the fundamental premise that each Member State shares with all the other Member States, and recognises that they share with it, a set of common values on which the Union is founded, as stated in Article 2 TEU. Therefore, the expectations from the candidates for EU membership are at the same level as for the Member States.

This premise of common values i. e. the rule of law has been gradually strengthened and enhanced throughout the last two decades of the enlargement process. The process started with the "Big Bang Enlargement" and the specific arrangements that were implied for the Bulgarian and Romanian entry into the EU through the Cooperation and Verification Mechanism. Later on, the EU put much more focus on Negotiating Chapter 23 and 24 during the Croatian negotiations constantly pointing out the importance of the rule of law in its negotiations with this candidate country.

Finally, this new approach of placing the rule of law and chapters 23 and 24 at the heart of the accession negotiation process was officiated in 2012 with the start of the accession talks with Montenegro. The European Council instituted "the new approach proposed by the Commission as regards the chapters on the judiciary and fundamental rights, and justice, freedom and security and" 39 and later on ,,urged Montenegro to tackle the issues of ... the independence of the judiciary, the fight against corruption and organised crime, and the need for Montenegro to step up its efforts in order to establish a solid track record in the course of the negotiations". ${ }^{40}$ This marked a new phase of accession negotiations where the Commission was tasked with identifying how a feasible and effective instrument could allow for more balanced and conditional accession talks based on progress in the rule of law. This approach, although somewhat extended to Chapter 35, ${ }^{41}$ was later also applied to Serbia when it opened the accession talks in 2014. Although this new approach allowed both candidate states to resolve the deadlock on opening new accession processes and to push forward with the opening of chapters. ${ }^{42}$ Montenegro and Serbia are still negotiating and still unable to fulfil the interim benchmarks ${ }^{43}$ for the rule of law chapters.

39 European Council Conclusions 9 December 2011, p. 5.

40 General Position on the Ministerial Meeting opening the Intergovernmental Conference on the Accession of Montenegro to the European Union, EU Opening Statement for Accession Negotiations, 8339/12, Brussels, 29 March 2012, p. 2.

${ }^{41}$ This otherwise usually empty chapter in the case of Serbia dialogue between Belgrade and Pristina.

${ }_{42}$ Pejović, A. A., Vladavina prava u politici prijema u Evropsku uniju, Matica crnogorska, No. 66, Podgorica, 2016, p. 24.

43 Interim benchmarks are a new generation of benchmarks that were inserted for chapters 23 and 24 within the new approach of negotiations with Montenegro and Serbia for the first time. They represent 
Four years after Serbia opened accession talks, in June 2018 the European Coun$\mathrm{cil}^{44}$ endorsed the conclusions on enlargement and Stabilisation and Association process previously adopted by the Council that set out "the path towards opening accession negotiations in June 2019 " 45 and convening an opening accession conference with Albania and North Macedonia by the end of 2019. However, the EU General Affairs Council decided to postpone their decision on opening negotiations to October 2019, ${ }^{46}$ and postpone it yet again in October $2019^{47}$ due to the lack of compromise in the Council. Finally, the decision was made on $25 \mathrm{March}$ 2020 during the first lockdowns in Europe, and after the European Commission presented its new methodology in the Communication entitled 'Enhancing the accession process - A credible EU perspective for the Western Balkans ${ }^{48}$ on 5 February 2020. The Council of the European Union, therefore, decided to open accession negotiations ${ }^{49}$ under the new methodological framework and invited the Commission to submit a proposal for negotiating framework with Albania in July 2020. This framework should establish the guidelines and principles governing the accession negotiations with the Republic of Albania and should be the basis of all the future work in the accession talks process. Although prepared and extensively discussed by the Member States throughout 2020, the document, however, has not been approved by the Council yet, meaning that the first intergovernmental conference can only be convened after the adoption of the negotiating framework by the Council.

\section{THE NEW ENLARGEMENT METHODOLOGY}

When the European Commission presented the new enlargement methodology, Member States expressed the expectation that this improved approach would lead to stronger political governance, based on objective criteria and with rigorous conditionality, which may be considered as both positive and negative. A part of

a mid-term mark of progress of a candidate in delivering results in the framework of action plans for these two chapters. Their fulfilment opens up the way to the adoption of closing benchmarks for these two chapters that guide the candidates to the overall conclusion of accession talks.

44 European Council Conclusions, Brussels, 28 June 2018, p. 10.

45 General Affairs Council Conclusions, 26 June 2018, 10555/18, p. 16 \& 19.

46 Outcome of the 3702nd Council meeting, General Affairs Council, Luxembourg, 18 June 2019, p. 4.

47 Outcome of the 3722nd Council meeting, General Affairs Council, Luxembourg, 15 October 2019, p. 3.

48 Communication from the Commission to the European Parliament, the Council, the European Economic and Social Committee and the Committee of the Regions, Enhancing the accession process - A credible EU perspective for the Western Balkans, Brussels, 5.2.2020 COM (2020) 57 final.

49 General Affairs Council Conclusions on Enlargement and Stabilisation and Association Process - the Republic of North Macedonia and the Republic of Albania, 7002/20, 25 March 2020. 
proposed changes will be applied not only to Northern Macedonia and Albania, but also integrated into existing negotiating frameworks with Montenegro and Serbia, ${ }^{50}$ which also expressed their intention to join the new methodology in the May and July 2020 respectively. The new methodology accentuated the need that the candidate countries would show their commitment to the strategic goal of joining the Union. The Commission also expressed the expectation that candidate countries should be even more committed to rule of law reforms in order to achieve deeper sectoral integration and overall progress.

One can say that the greatest novelty in the new enlargement methodology is the new architecture of clusters of chapters. The Commission expects the clusters to provide a stronger focus on key sectors in the political dialogue, and that the candidate country could decide which are the most important and urgent reforms by sector. The negotiating chapters are organised in six thematic clusters to bring together the chapters or areas according to broader themes and to allow for a stronger focus on core sectors. Negotiations on each cluster are opened as a whole, with all chapters within the cluster opened simultaneously. The most important Cluster is the first one - the Fundamentals. It is covering the two rule of law chapters 23 and 24, along with the three more chapters on public procurement (5), statistics (18) and financial control (32), as well as the economic criteria, functioning of democratic institutions and public administration reform. Here, one can notice that the issues that are of the greatest interest for the rule of law and the proper functioning of the budget are actually being joined in the fundamentals' cluster.

The negotiations on the fundamentals area will be opened first and concluded last. This will be a very important requirement for the countries that are to open talks, but to Montenegro and Serbia it will impact only the closing phase. Interim benchmarks will still remain for the rule of law chapters within the first cluster, but in the improved new approach, the provisional closures of any chapter will no longer be possible before the interim benchmarks for the fundamentals cluster are fulfilled. The fundamentals cluster, in addition to the rule of law, implies the adoption of additional roadmaps - on the functioning of democratic institutions and public administration reforms.

The new methodology brought more innovations in relation to the mechanism for monitoring progress and the role of the Commission and the Council. In addition to supporting progress in reforms through progress in the negotiation process and financial support, the need for proportionate sanctions for any serious or prolonged stagnation or even lagging behind in implementing reforms and meet-

50 Non-paper on the application of the revised methodology to Montenegro and Serbia. 
ing the requirements of the accession process was emphasised. In serious cases, the Commission will still be able to make proposals to the Council, independently of the annual report, at any time on its own or at the request of a Member State. Member States are thus called upon to make a more systematic contribution to the accession process. On top of that, the EU Member States have been given another more powerful tool in their relations with the Commission through the new methodology. In contrast to the 2012 Enlargement Methodology, when one third of Member States were needed to launch an initiative towards the Commission in the event of breaches of the rule of law, ${ }^{51}$ the enhanced 2020 approach brought the possibility that only one Member State can do so. In the context of decisionmaking in the Council of the EU, Member States could, upon a proposal, decide to postpone negotiations in certain areas, or in the most serious cases, to fully suspend them. Furthermore, already closed chapters can be reopened or rearranged in case certain issues need to be reconsidered.

\section{FINANCIAL CONDITIONALITY IN THE NEW METHODOLOGY}

The new approach envisages increased investments and funding if a candidate country makes sufficient progress on reform priorities agreed in the negotiations. This would also cover an increased access to pre-accession assistance in line with applicable legal provisions, rules and procedures and a closer cooperation with relevant International Financial Institutions to leverage investments and support. On the other hand, the scope and intensity of pre-accession assistance may also be scaled down in accordance with applicable rules and procedures. An exception to this possible reduction in pre-accession funds would be civil society organisations in the candidate countries.

Unlike the Conditionality Regulation, the downward adjustment of pre-accession assistance has not been elaborated either in the new enlargement methodology or the negotiation frameworks for North Macedonia and Albania. One can only imagine how the procedure would or could be further set down in order to cover the situations in which the EU decides to reduce the funding under the instrument for pre-accession (IPA). Some of the examples that took place in the past offer some ideas but they have been ad hoc solutions for very specific situations. Here, the case of Bosnia and Herzegovina provides an illustrative example.

51 Article 22 of the General Position on the Ministerial Meeting opening the Intergovernmental Conference on the Accession of Serbia to the European Union, EU Opening Statement for Accession Negotiations, AD1/14 Brussels, 21 January 2014, p. 9. 
When IPA II for Bosnia and Herzegovina was being planned, an amount of EUR 165.8 million was determined only for the period 2014-2017 instead of 20142020 like the other pre-accession countries. ${ }^{52}$ The reasoning was that Bosnia and Herzegovina did not meet the first criterion of sectoral approach - the existence of sectoral strategies at the state level, which meant that they could not get help for key sectors: agriculture and rural development, transport, environment and energy - until they adopted them. Bosnia and Herzegovina was at the time gradually moving towards the sectoral approach, but its main weaknesses was the lack of harmonised countrywide strategies in key sectors with clear budget allocations and a medium-term expenditure framework. The way Bosnia and Herzegovina is structured with multiple levels of governance and lack of functional coordination and policy-making mechanisms between the different levels impeded the establishment of solid sector and donor coordination of the country.

This was corrected only during the 2018 revision ${ }^{53}$ when the full amount was determined for all seven years 2014-2020 in the amount of EUR 552.1 million. The adoption of a coordination mechanism in EU matters in 2016 was a crucial step forward that allowed for the harmonisation of positions on EU matters among various state and entities' stakeholders in their shared competences. Furthermore, seven sectors met the pre-conditions for implementation of sector approach under IPA II in the period 2018-2020 based on countrywide sector strategies. Once the deficiencies were removed and there was an agreement between the EU and Bosnia and Herzegovina that all the conditions had been met, the full seven-year allocation for Bosnia and Herzegovina was approved.

As one can see, in contrast to the regulated and very defined procedures and roles of various institutions, in the case of postponement of programming the full seven-year allocation for Bosnia and Herzegovina, this was done without any specific prescribed rules, on an ad hoc basis and through the initiative and decisionmaking processes of the Commission. Considering the notion of the possibility of adjusting the pre-accession assistance in relation to the situation with the rule of law and the deficiencies thereof in the enlargement countries, it would be very important to see if the EU should prescribe the procedures for these cases. The institutions of the EU have a tendency towards heavily regulating procedures that have to tackle sensitive and risky situations, as one can notice in the Article 7 and Conditionality Regulation procedural requirements. The negotiation frameworks for North Macedonia and Albania, on the other hand, regulates in detail a whole

\footnotetext{
52 More information on the allocations for the accession countries in: Pejović, A. A., Instrument pretpristupne podrške Evropske unije 2007-2027, Evropsko zakonodavstvo, No 72, Beograd, 2020, pp 16-29.

53 Revised Indicative Strategy Paper for Bosnia and Herzegovina (2014-2020) adopted on 3 August 2018.
} 
number of very elaborate corrective measures on proportional sanctioning of any serious or prolonged stagnation or even backsliding in reform implementation and meeting the requirements of the accession process.

In the case the EU would really aim to utilise the proposed suspension or downscaling to pre-accession assistance, a further elaboration and specification of the rules and procedures would be necessary if one wants to bring more transparency and understanding to the whole process. It would also allow for both parties to understand what the risks, requirements and procedures could be. However, neither the new enlargement methodology nor the negotiation frameworks for Albania and North Macedonia give any hint that this procedure will be further regulated.

\section{RULE OF LAW IN THE CONTEXT OF THE COVID-19 PANDEMIC}

What one needs to be aware of is that both the process of strengthening the rules of protection of financial interests of the EU for its Member States and an ever-more stringent conditionality in the enlargement process are operating in very specific surroundings of the Covid-19 virus and its overwhelming impact on Europe and beyond. Ever since the start of the pandemic in Europe, this specific crisis has delayed or slowed down a number of processes and ordinary procedures in the EU. In spite of initial progress including hearings in 2018 and 2019, the proceedings against Poland and Hungary, have almost completely stopped. Apart from that, in aiming to address the pandemic, the measures taken by the governments of certain member states have been seen as a breach of human rights and freedoms due to the state of emergency. Therefore, in a state of emergency, it is not disputable that certain rights and freedoms are revoked because the constitution and laws allow it, but the real issue, like most things related to the content of the rule of law, is related to the scope and depth of these special measures which are assigned during the emergency state, as well as the internal and external reactions to them. For example, the Polish ruling party PiS changed the election legislation in the middle of the pandemic, in order to allow voting by mail, which prompted thirteen EU member states to issue a diplomatic statement ${ }^{54}$ in which they expressed deep concern over the risk of violating the principles of the rule of law, democracy and fundamental rights arising from the adoption of certain urgent measures.

54 Government of the Netherlands, Statement by Belgium, Bulgaria, Cyprus, Denmark, Estonia, Finland, France, Germany, Greece, Ireland, Italy, Latvia, Lithuania, Luxembourg, the Netherlands, Portugal, Romania, Spain, Sweden, Diplomatic Statement, 1 April 2020. 
The same postponement and stagnation of decision-making processes have been visible in the cases of Albania and North Macedonia and their opening of accession talks. Although this was coupled with the reluctance of certain Member States to commence negotiations with new candidate countries. Notwithstanding, the Covid-19 pandemic has also taken its toll on the whole process. Lack of contacts, conferences and meetings have insulated the stakeholders and prevented any real diplomatic communication or lobbying for the official initiation of accession talks.

On the other hand, the Recovery Next Gen Fund has been created to address the urgent needs of the EU Member States in countering and mitigating their problems with the economic, financial and social effects of the virus. Since huge sums will be released in the course of the implementation of the Next Gen funding, the protection of financial interests and the focus on the rule of law as a key requirement will have to find a way to function together. Apart from the disbursement of the EU budget funding, the Next Gen will add to the pressure on the releasing of much more funds than planned, which would also leave less time for the usually sensitive and reluctantly triggered mechanisms in the cases of the rule of law breaches.

\section{CONCLUSIONS}

Further deterioration of the situation with the rule of law is inescapably going to impact the EU's stability and its future internal integration as well as its enlargement. The rule of law is slowly but consistently creating more and more pressure on the Member States and the EU institutions to find a viable solution acceptable for all parties. Unlike the other issues that overburden the Union, the rule of law controversy destabilises the very foundations of the European project as it touches the core values of the Member States. This has far-reaching consequences and a significant impact on the manner how the EU will build its mechanisms to protect the core values it is based on and thus survive as a union of values.

The EU has developed various mechanisms and tools in recent years to protect the fundamentals of the TEU Article 2. The recently invoked TEU Article 7 procedure, setting up the European Public Prosecutor's Office, upgrades to the Rule of Law Framework and the annual reports on the rule of law - they have all been topped up with a conditionality regulation that would be used to restrict access to the EU funds for actors whose actions constitute the violations of the rule of law.

The latest enlargements have also to a great extent changed the way the EU operates and how it perceives the possibilities of any future entry into the Union. The 
last decade oversaw a gradual metamorphosis of the enlargement policy into a tool that is more and more based on strict conditionalities and requirements putting the rule of law at the heart of the process. This has led to a situation where none of the current candidate countries that is either conducting negotiations or is preparing to initiate them can hope to enter the EU in a short-term perspective. The rule of law conditionality brings more complicated and complex conditions on opening and closing chapters, together with very elaborate mechanisms of suspension, blocking and regressing in the accession procedures. This dents the prospects of the enlargement countries to such a degree that no one can predict their date of entry into the Union. Although the provisions on reducing the scope and intensity of pre-accession assistance to candidate countries in the cases of no progress, imbalance of the overall negotiations or the regression have not been specified and further developed in any of the recent enlargement documents, the insertion of this notion into the new enlargement mechanisms is bringing a potential game-changer in the manner pre-accession funds are being disbursed. Now, not only that a candidate country may be suspended or fully stopped in its integration efforts, but it may also lose a part or considerable amount of its pre-accession allocations.

What has become clear, is that the EU is moving towards increasingly developed mechanisms for dealing with possible deficiencies or breaches of the rule of law in connection to the financial tools that the Union has at its disposal, be it its structural funds or pre-accession instruments. The Covid-19 pandemic has added to the problem with the shift of focus to other domains beyond the rule of law. Furthermore, the pandemic has had a stagnating impact on the procedures. Nevertheless, no matter how the pandemic unfolds in the coming period, one can conclude that the already-commenced instruments of monitoring and protection of the rule of law will be further strengthened both in the internal and external policies of the Union.

The Conditionality Regulation comes as an energising new addition in the already long process of struggle to find a common solution for the rule of law respect and protection in the EU. It has tried to rectify the deficiencies of Article 7 procedures and to build upon the latest rule of law framework mechanisms such as the annual reports of the Commission. Now, the focus is on the financial means, an important part of the EU agenda, especially for the pockets of the Member States that joined the Union in 2004 and later. A timid initiative to duplicate this approach onto the access to pre-accession funds in the new enlargement framework, would need to rely on the success of the Conditionality Regulation once it comes to life in order to become as applicable for candidate states as it is with the Member 
States. Whether money would finally start to make a difference in both processes, remains only to be seen.

\section{REFERENCES}

\section{BOOKS AND ARTICLES}

1. Beaulac S., What Rule of Law Model for Domestic Courts Using International Law in States in Transition: Thin, Thick or 'A La Carte', Transitional Justice Institute Research Paper No. 10-13, 2019, p. $1-27$

2. Cramer, P.; Wrange P., The Haider Affair, Law and European Integration, SSRN Electronic Journal, 2001, p. 28-60

3. Heinemann, F., Going for the Wallet? Rule-of-Law Conditionality in the Next EU Multiannual Financial Framework, Inter-economics, Vol. 53, No. 6, Nov.-Dec. 2018, p. 297-301

4. Kochenov, D., The Acquis and Its Principles, The Enforcement of the 'Law' versus the Enforcement of 'Values' in the EU, in: Jakab, A.; Kochenov, D. (eds.), The Enforcement of EU Law and Values, Ensuring Member States' Compliance, Oxford University Press, Oxford, 2017, p. 9-28

5. Kochenov, D.; Bard, P., Rule of Law Crisis in the New Member States of the European Union: The Pitfalls of Overemphasising Enforcement, Reconnect, 2018. p. 1-26

6. Lenaerts, K., New Horizons for the Rule of Law Within the EU, German Law Journal, CUP, 2020, p. 29-34

7. Matić Bošković, M., Role of Court of Justice of the European Union in Establishment of EU Standards on Independence of Judiciary, EU and Comparative Law Issues and Challenges Series (ECLIC), Vol. 4, Osijek, 2020, p. 329-351

8. Palombella, G., The Rule of Law as an Institutional Ideal, The Rule of Law and Democracy, in: Morlino, L.; Palombella, G., (eds.), Internal and External Issues, Brill Publishing, 2010, p. $1-33$

9. Pech, L.; Wachowiec, P.; Mazur D., Poland's Rule of Law Breakdown: A Five-Year Assessment of EU's (In)Action, Hague Journal on the Rule of Law, The Hague, 2021, p. 1-43

10. Peerenboom, R. Varieties of Rule of Law: An Introduction and Provisional Conclusion, Asian Discourses of Rule of Law, Routledge Curzon, 2014, p. 1-55

11. Peirone F., The Rule of Law in the EU: Between Union and Unity, 15 Croatian Yearbook of European Law \& Policy, No. 57, Zagreb, 2019, p. 57-98

12. Pejović, A. A., Instrument pretpristupne podrške Evropske unije 2007-2027, Evropsko zakonodavstvo, No. 72, Beograd, 2020, p. 16-29

13. Pejović, A. A., Vladavina prava u politici prijema u Evropsku uniju, Matica crnogorska, No. 66, Podgorica, 2016, p. 7-24

14. Raz, J., The Rule of Law and Its Virtue, in: Raz, J. (eds.), The Authority of Law: Essays on Law and Morality, Clarendon Press, Oxford, 1979, p. 208-226

15. Skaaning, S.; Moller, J., Systematizing Thin and Thick Conceptions of the Rule of Law, APSA 2010 Annual Meeting Paper, 2010, p. 136-153 
16. Tamanaha, B., On the Rule of Law, History, Politics, Theory, Cambridge University Press, Cambridge 2004

17. Viorica, V., Revisiting the Dominant Discourse on Conditionality in the EU: The Case of EU Spending Conditionality, Cambridge Yearbook of European Legal Studies, Centre for European Legal Studies, Cambridge, 2017, p. 116-143

18. Vlajković, M., Uslovljavanje u spoljnoj politici Evropske unije: Izazovi pravno-političkog „izvoza" vrednosti u susedstvo, Međunarodno javno i krivično pravo u XXI veku, Udruženje za međunarodno krivično pravo, Tara, 2020, 313-323

\section{EU LAW}

1. Application of Regulation (EU, Euratom) 2020/2092, the rule of law conditionality mechanism (debate), European Parliament, 11 March 2021, [https:/www.europarl.europa.eu/doceo/ document/CRE-9-2021-03-11-ITM-005_EN.html], Accessed 15 April 2021

2. Communication from the Commission to the European Parliament, the European Council and the Council, Further strengthening the Rule of Law within the Union State of play and possible next steps, COM/2019/163 final Brussels, 3 April 2019

3. Communication from the Commission to the European Parliament, the European Council, the Council, the European Economic and Social Committee and the Committee of the Regions Strengthening the rule of law within the Union, A blueprint for action COM/2019/343 final, 17 July 2019

4. Communication from the Commission to the European Parliament, the Council, the European Economic and Social Committee and the Committee of the Regions, Enhancing the accession process - A credible EU perspective for the Western Balkans, Brussels, 5 February 2020 COM (2020) 57 final

5. Communication from the Commission to the European Parliament, the Council, the European Economic and Social Committee and the Committee of the Regions - 2020 Rule of Law Report, The rule of law situation in the European Union, COM/2020/580 final, Brussels, 30 September 2020

6. Council Directive 2001/29/EC on the harmonisation of certain aspects of copyright and related rights in the information society [2001] OJ L167/10

7. European Council Conclusions, Copenhagen, 21-22 June 1993

8. European Council Conclusions, Brussels, 9 December 2011

9. European Council Conclusions, Brussels, 28 June 2018

10. European Council Conclusions, Brussels 17-21 July 2020

11. European Council Conclusions, Brussels 10-11 December 2020

12. European Commission for Democracy through Law (Venice Commission) Rule of Law Checklist, CDL-AD (2016)007rev, Strasbourg, 18 March 2016

13. European Parliament resolution of 25 October 2016 with recommendations to the Commission on the establishment of an EU mechanism on democracy, the rule of law and fundamental rights $(2015 / 2254$ (INL))

14. General Affairs Council Conclusions, 26 June 2018, 10555/18 
15. General Affairs Council Conclusions on Enlargement and Stabilisation and Association Process - the Republic of North Macedonia and the Republic of Albania, 7002/20, 25 March 2020

16. General Position on the Ministerial Meeting opening the Intergovernmental Conference on the Accession of Montenegro to the European Union, EU Opening Statement for Accession Negotiations, 8339/12, Brussels, 29 March 2012

17. General Position on the Ministerial Meeting opening the Intergovernmental Conference on the Accession of Serbia to the European Union, EU Opening Statement for Accession Negotiations, AD1/14 Brussels, 21 January 2014

18. Government of the Netherlands, Statement by Belgium, Bulgaria, Cyprus, Denmark, Estonia, Finland, France, Germany, Greece, Ireland, Italy, Latvia, Lithuania, Luxembourg, the Netherlands, Portugal, Romania, Spain, Sweden, Diplomatic Statement, 1 April 2020

19. Motion for a Resolution to wind up the debate on the statements by the Council and the Commission pursuant to Rule 132(2) of the Rules of Procedure on the Multiannual Financial Framework 2021-2027, the Inter-Institutional Agreement, the EU Recovery Instrument and the Rule of Law Regulation (2020/2923(RSP)

20. Non-paper on the application of the revised methodology to Montenegro and Serbia

21. Outcome of the 3702nd Council meeting, General Affairs Council, Luxembourg, 18 June 2019

22. Outcome of the 3722nd Council meeting, General Affairs Council, Luxembourg, 15 October 2019

23. Proposal for a Council Regulation laying down the multiannual financial framework for the years 2021 to 2027, COM/2018/322 final - 2018/0132 (APP)

24. Regulation (EU, Euratom) 2020/2092 of the European Parliament and of the Council of 16 December 2020 on a general regime of conditionality for the protection of the Union budget

25. Report on the Austrian Government's Commitments to the Common European Values, in Particular Concerning the Rights of Minorities, Refugees and Immigrants, and the Evolution of the Political Nature of the FPO (The Wise men Report) by Martti Ahtisaari, Jochen Frowein, Marcelino Oreja, adopted in Paris on 8 September 2000

26. Resolution on the application of Regulation (EU, Euratom) 2020/2092, the rule-of-law conditionality mechanism, 2021/2582(RSP), Brussels, 25 March 2021

27. Revised Indicative Strategy Paper for Bosnia and Herzegovina (2014-2020) adopted on 3 August 2018

28. Summary of 2014-2020 EU budget amounts assigned to EU countries for support for specific programmes in the Cohesion Policy and the Common Agricultural Policy, European Commission, [https://ec.europa.eu/info/strategy/eu-budget/long-term-eu-budget/2014-2020/ spending/pre-allocations_en], Accessed 15 April 2021

29. Treaty of Lisbon amending the Treaty on European Union and the Treaty establishing the European Community [2007] OJ C306/01 


\section{COURT OF JUSTICE OF THE EUROPEAN UNION}

1. Advocate General's Opinions in Cases C-487/19 W.Ż. (Chamber of Extraordinary Control and Public Affairs of the Supreme Court - Appointment) and C-508/19 Prokurator Generalny (Disciplinary Chamber of the Supreme Court - Appointment)

2. Case 294/83 Les Verts v. Parliament (1986), EU:C:1986:166

3. Case C64/16, Associação Sindical dos Juízes Portugueses, (2018) EU:C:2018:117

4. Case C216/18 PPU, Minister for Justice and Equality (Deficiencies in the system of justice), (2018) EU:C:2019:551

\section{LIST OF NATIONAL REGULATIONS, ACTS AND COURT DECISIONS}

1. BVerfG, Judgment of the Second Senate of 5 May 2020 - 2 BvR 859/15 -, paras. 1-237

2. Skarga do Trybunatu Sprawiedliwości UE, Kancelaria Prezesa Rady Ministrow - [https:// www.gov.pl/web/premier/skarga-do-trybunalu-sprawiedliwosci-ue], Accessed 15 April 2021

\section{WEBSITE REFERENCES}

1. Alemanno, A., The EU Parliament's Abdication on the Rule of Law (Regulation), VerfBlog, 2021/2/25, [https://verfassungsblog.de/the-eu-parliaments-abdication-on-the-rule-of-lawregulation/], Accessed 15 April 2021

2. Democracy Institute Event Offers Debate on the Rule of Law in Europe, Central European University, 26 January 2021, [https://www.ceu.edu/article/2021-01-26/democracy-instituteevent-offers-debate-rule-law-europe], Accessed 15 April 2021

3. Gehrke, L. How Europe reacted to the new EU budget and coronavirus recovery fund deal, Politico, 21 july 2020 [https://www.politico.eu/article/madness-and-historic-day-europereacts-to-the-budget-deal/], Accessed 15 April 2021

4. Maukonen, R., Vèra Jourová: "EU underestimated the role of media in upholding democracy", International Press Institute, 2021, [https://ipi.media/vera-jourova-eu-underestimated-therole-of-media-in-upholding-democracy/], Accessed 15 April 2021

5. Poland and Hungary file complaint over EU budget mechanism, DeutscheWelle, 11 March 2021, [https:/www.dw.com/en/poland-and-hungary-file-complaint-over-eu-budget-mecha nism/a-56835979], Accessed 15 April 2021

6. Scheppele, K. L.; Pech, L.; Platon, S., Compromising the Rule of Law while Compromising on the Rule of Law, VerfBlog, 2020/12/13, [https://verfassungsblog.de/compromising-the-ruleof-law-while-compromising-on-the-rule-of-law/], Accessed 15 April 2021.

7. Zalan, E., Poland and Hungary challenge rule-of-law tool at EU court, euobserver, 12 March 2021, [https://euobserver.com/political/151211], Accessed 15 April 2021 